Gerald P. Dwyer, $J t$, an associate professor of economics at the University of Houston, is a visiting scholar at the Federal Resenve Bank of St. Louis. R. W. Hafer is a research officer at the Federal Resene Bank of St. Louis. Nancy D. Juen provided research assistance.

\title{
Is Money Irrelevant?
}

$\mathbf{M}$ ing that money has little or no effect on inflation and economic activity. For example, Lyle F. Gramley, past governor of the Federal Reserve Boand, has been quoted as saying "the relationship be" tween growth of the economy and the growth of the money supply is just no Ionger there." Meanwhile, even a noted monetarist such as Beryl $W$. Spunkel, the current chaiman of the Council of Economic Advisers, says: "It's a problem. Nobody knows where we are going."

These recent statements are hardly novel, nor have they changed all that much over the years. In 1971, Federal Reserve Board Governor Andrew $F$. Brimmer noted that if has "not [been] demonstrated convincingly that the relationship between the money supply and economic activity is especially close."

The overriding question seems to be how well money growth predicts economic activity over some horizon. In this paper we offer a brief dis- cussion of how changes in the growth of the money supply affect the economy in the long run Following this, we use cross-sectional data based on a large number of countries to see how well the offered theory holds up to the facts. We also illustrate that the connection between changes in money growth and economic activity is quite loose over short time periods. The upshot of our findings is that, even today, one cannot dismiss the proposition that, in the long run, increases in the growth of the money supply will increase inflation and have no lasting effect on real economic activity.

\section{SOMR TASTC PROPOSTINNS}

The basic propositions discussed are derived from the quantity theory. Basically, this theory states that, in the long run, changes in money growth are reflected one-for-one in nominal income growth and inflation but have no impact on the output of real goods.
See Kilborn (1986).

2fbid. Among other things, monetarism is characterized by the proposition that there is a direct and proportional linkage between changes in the growth of the money supply and nominal economic variables, like inflation and nominal income growth. In addition, money growth changes have no infiuence on real economic activity. The effects on nominal income and inflation hold in the long run, a point discussed later in this article. See Brunner (1968), who coined the term monetarist, for a discussion of these and other issues.

\section{Quoted in Francis (1972).}

4Many economists who would not call themselves quantity theorists or monetarists probably would subscribe to the following propositions. 


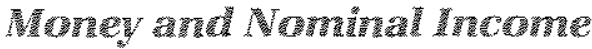

Going back at least to Irving Fisher (1911) and Arthue C. Pigou (1917), the first proposition is:

Proposition I: Changes in the money supply are associated with changes in spending and nominal income.

This proposition results from an analysis of the demand for and the supply of money, which can be discussed conveniently in terms of the quantity equation,

(1) $\mathbf{M}=\mathbf{k Y}$,

where $M$ is the nominal quantity of money, $k$ is households' and firms' desired ratio of money to income, and $Y$ is nominal income. In the first instance, $M$ can be interpreted as the quantity of money demanded by firms and households. If the amount of money households and firms want to hold relative to income is constant, equation 1 simply says that an increase in nominal income will increase the quantity of money demanded a plausible statement.

Saying anything about the effects of changes in the money supply on income requires a supposition about the relationship between the quantity of money demanded and supplied. At least over longer periods of time, the quantity of money demanded and the quantity supplied are the same." Under this supposition, equation 1 says that the quantity of money supplied equals households' and firms ${ }^{\prime}$ desired ratio of money to income multiplied by nominal income. If the quantity of money supplied increases, either $k$, the desired ratio of money to income, or $\mathrm{Y}$, nominal income, must increase.

What actually happens if the quantity of money in an economy suddenly increases? The addi" tional money will be held: it is a rare person who burns money. Assuming that nominal income and households' and firms' desired ratio of money to income initially are unaffected, firms and households momentarily are holding more money than they want to hold. What will they do? They will spend some of it. To the extent the additional money is spent on final goods and services, Gross National Product the dollar value of such spending) increases. Because Gross National Product also is a measure of nominal income, an increase in the quantity of money supplied increases both spending and income.

A strong corollary of this first proposition is:

Proposition Ia: An increase in the growth rate of money will be matched by an equal increase in the growth rate of nominal income.

When the quantity equation is written in terms of the growth rates of money, the desired ratio of money to income, and income, it becomes

(2) $\stackrel{+}{\mathrm{M}}=\dot{\mathrm{k}}+\dot{\mathrm{Y}}$,

where the dots over variables indicate their growth rates. If the growth rate of $k$, firms' and households' desired ratio of money to income, is independent of changes in the growth rate of the money supply, then changes in the growth of the money supply must be matched one-for-one by changes in the growth of nominal income. In other words, holding $\dot{k}$ constant, a 1 percentage point increase in money growth is associated with a 1 percentage point increase in nominal income growth.

This proposition is a long-run proposition. Suppose, for example, that the growth rate of the money supply has been 10 percent per year for a long time and the growth rate of $k$ is 4 percent. Then, from equation (2), the growth rate of nominal income is 6 percent. If the growth rate of the money supply increases from 10 to 15 percent, the growth rate of nominal income will not increase from 6 percent to 11 percent immediately. It will be some time before the increase in spending occurs and the economy completely adjusts to the changed circumstances. The speed with which firms and households increase their spending after an increase in the money supply is affected by other things in the economy. Eventually the economy will adjust, but as the data we present below indicate, the adjustment period may exceed one year.

\footnotetext{
${ }^{5}$ Actually, a lot of evidence is consistent with it as well. A good summary is provided by Laidler (1977).

'This difference between the quantities of money demanded and supplied is contingent on a simple specification of equation 1. In a fully-specified model of the demand for money with all adjustment costs and state variables included, the quantity of money demanded always equals the quantity of money supplied.
}

Interest rates and expectations about future inflation are two such factors. Gavin and Dewald (1987, pp. 22-24) present some interesting evidence for 39 countries consistent with the importance of changes in expected inflation. 
While nominal income growth clearly is of some interest, the breakdown of nominal income growth into real growth and inflation is perhaps even more informative about the state of the economy. By definition, nominal income is the price level times real income. In terms of growth rates, the growth rate of nominal income equals the rate of increase of prices plus the growth rate of real income, or

\section{(3) $\dot{\mathrm{Y}}=\dot{\mathrm{p}}+\dot{\mathrm{y}}$,}

where $\dot{P}$ is the rate of increase of the price level (the inflation rate), and $\dot{y}$ is the growth rate of real income. As equation 3 indicates, nominal income growth of 5 percent per year could occur with no inflation and real income growing at 5 percent per year. On the other hand, inflation could be 25 percent per year with real income falling 20 percent per year. Clearly, any given growth rate of nominal income can be associated with quite different inflation rates and real income growth rates.

\section{Money and Real ncome}

A second proposition, pointed out forcefully by David Hume (1752), is:

Proposition II: Changes in the money supply are not associated with permanent changes in real income.

With respect to real income growth, changes in the growth of money will have no effect. The basis for this proposition is quite simple. Real income and output, the quantity of goods and services produced, are the same thing. Over long periods of time, the quantity of goods and services produced in an economy is determined by the quantity of resources applied to producing goods and services, including land, labor and capital, as well as technology, workers' skills and knowledge. Under most circumstances, money plays a very minor role in the long run. Large changes in the growth of the money supply, for example a change from 0 to 1,000 percent per year, can sufficiently disrupt an economy that real income falls. Small changes, however, are unlikely to have such an effect ${ }^{8}$

\section{Money and hathon}

The third proposition is about inflation:

Proposition III: An increase in the growth rate of money, other things the same, will be matched by an equal increase in the rate of inflation.

This proposition is derived from the two earlier ones. If changes in the growth rate of the money supply are associated one-for-one with changes in nominal income growth, then changes in the growth of the money supply must change real income growth or the inflation rate. The combination of the two propositions above implies that, in the long run, only the inflation rate is affected. Consequently, if the growth rate of money increases by 1 percentage point per year, then the inflation rate eventually must increase 1 percentage point per year as well.

This one-forme relationship between the growth of the money supply and the inflation rate is the result of a relationship between money and spending which takes time to be played out, combined with the lack of a long-run relationship between money and real income. It would be surprising if this third proposition held each month, quarter or year. The length of the period over which it does apply is examined below.

\section{TIE DATA}

These propositions can be examined in a variety of ways. One approach is to look at data for a specific country over a long time span, say, 100 years. Another approach, the one adopted here, is to use data across a large number of countries for a shorter time period. Because the propositions are, as Robert Lucas has noted, "characteristics of steady states [that is, long ${ }^{\prime}$ run equilibria], . . the ideal experiment for testing them would be a comparison of long-term average behavior across economies with different monetary policies but similar in other respects."

The specific data set that we use includes data on nominal income, real income, the price level and the money stock for 62 countries. Income and the associated price indexes are calculated using
${ }^{8}$ Changes in the money supply can be related to changes in real income. Indeed, many economists argue that, in one way or another, changes in the money supply are positively related to short-run changes in real income. This relationship is used to explain the changes in real income associated with business. fluctuations. tucas (1980), p. 1006. This approach has been used by, among others, Schwartz (1973), Lothian (1985) and Lucas (1986). 
either Gross National Product (GNP) or Gross Domestic Product (GDP) : Nominal and real GNP are used if they are available and the price level is measured by the GNP deflator; otherwise, nominal and real GDP are used and the price level is measured by the GDP deflator." The countries and the data are presented in the appendix.

The "long-term" growth rates for the economic variables used are avenages of annual growth rates for five years, 1979 to $1984{ }^{\text {.z }}$ The "short-term" growth rates are annual growth rates for individ ual years. The focus on the recent period is deliberate: the relevance of money in recent years has been challenged. Therefore, a key issue is whether the propositions discussed above are supported by the data from the past few years.

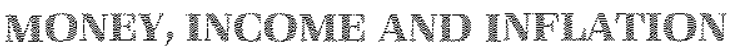

\section{The Dors-}

The first proposition states that there is a oneto-one relationship between money growth and the growth of nominal income. To see if this is true, the long-run growth rates of money and income for the countries in our sample are shown in figure $1 .^{13}$ The scatter of points indicates that the data are consistent with this proposition. As the figure shows, there is a wide diversity in experim ence across countries. For 1979 to 1984 , average money growth rates range from about 2 percent per year for Switzerland to 220 percent per year for Bolivia. The growth rate of nominal income also varies substantially, from about 5 percent per year for the United Arab Emirates to about 200 percent per year for Bolivia. More important, the points tend to lie on the reference line in the figure, which has a slope of one. This clustering of income and money growth rates along the line

\section{Table 1}

Income and Inflation Regressions: 1979 to 1984

\begin{tabular}{|c|c|c|c|}
\hline \multirow[b]{2}{*}{$\begin{array}{l}\text { Dependent } \\
\text { varioble }\end{array}$} & \multicolumn{2}{|c|}{ coerficient estmates } & \multirow[b]{2}{*}{ fe } \\
\hline & Constant & $\begin{array}{l}\text { Growthrate } \\
\text { ormoney }\end{array}$ & \\
\hline $\begin{array}{l}\text { Growih rate of } \\
\text { nominalicome }\end{array}$ & $\begin{array}{l}7.592 \\
(1.128)\end{array}$ & $(10027)$ & 096 \\
\hline growlh rafe of & $\begin{array}{l}2.613 \\
(0.366)\end{array}$ & $\begin{array}{r}-0018 \\
(0,009)\end{array}$ & 0.07 \\
\hline Inflation rate & $(1,054$ & $(0025)$ & 096 \\
\hline
\end{tabular}

indicates a one-for-one correspondence between the two consistent with proposition I.

To examine this proposition another way, we present a simple regression using the data in figure 1 in the first line of table 1 . This regression is the estimated straight line which best fits the data for nominal income growth and money growth. ${ }^{\text {:4 }}$ The regression is consistent with our observations about the graph. The estimated coefficient for money growth is 1.007 , which indicates that an increase in money growth of 1 percentage point per year is associated with an increase in nominal. income growth of almost exactly 1 percentage point per year. In addition, the statistic measuring the fraction of variation explained, the $\mathbf{R}^{2}$, shows that 96 percent of the variation in the nominal income growth rates is explaned by money growth. This corroborates the graphic evidence that money and nominal income growth are closely linked.
${ }^{10} \mathrm{GNP}$ is defined as the current market value of all final goods and services produced by labor and property supplied by resictents of the country. GDP is the current market value of all final goods and services produced by labor and property located in the country.

"The deflator simply is calculated as the ratio of nominal income to real income; for example, the GNP defiator is nominal GNP divided by rea: GNP.

${ }^{12} \mathrm{Although}$ one may quibble whether five years is long enough to be long run, it seems to be fong enough for transitory disturbances to average out.

${ }^{13}$ The propositions imply that the slope of the reference line should be one for nominal income growth and inflation. They do not imply that the lines pass through the origin, but they are drawn through the origin for convenience.
${ }^{14}$ The estimation technique used is ordinary least squares, which defines the "best" straight line as the one which minimizes the total sum of squared deviations of the dependent variable from the estimated line. The numbers in parentheses in the table are the standard errors of the estimated coefficients. These statistics are useful for testing hypotheses about the estimated coefficients. For example, suppose one wishes to determine whether the estimated coefficient is statistically different from zero. One need only divide the estimated coefticient by its standard error. If the resulting value - known as a t-statistic exceeds some predetermined value, say 2 , then the coefficient is said to be significantly different from zero. Another way of evaluating these regression results is to test whether the coefficient equais one. To test the hypothesis that an estimated coefficient is equal to one, the estimated coefficient minus one is divided by the reported standard error. A t statistic less than 2 means that the hypothesis that the estimate equals one cannot be rejected. 


\section{Chart 1 \\ Growth in Nominal GNP and Growth in Money: 1979 to 1984}

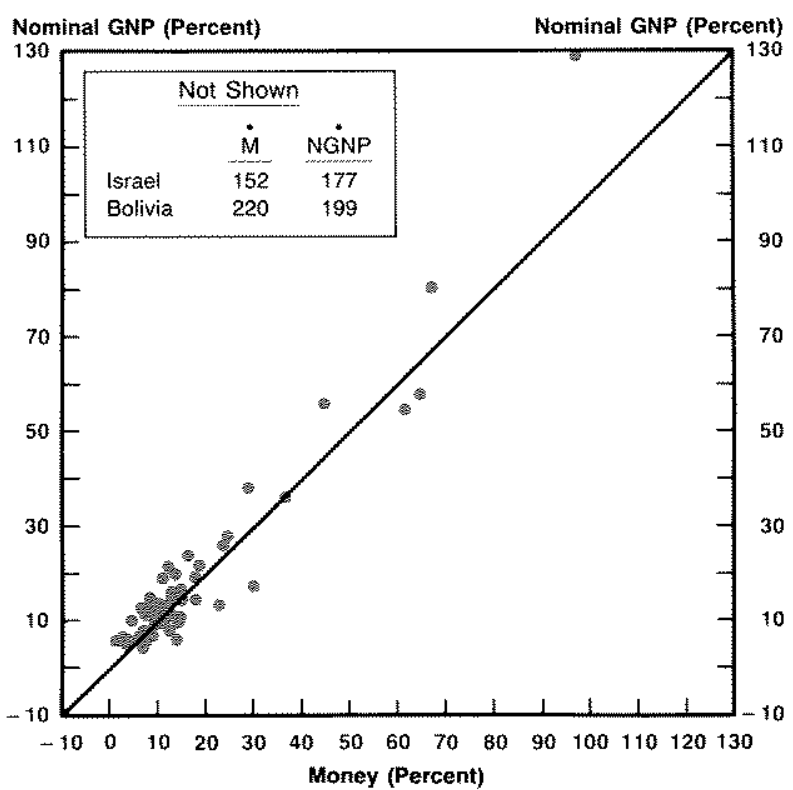

The second proposition concerns the independence of money and real income growth in the long run. Figure 2 shows the countries" average money growth and real income growth rates for 1979 to 1984 . In this figure, the reference line is drawn at the average real income growth rate across the countries. This line has a slope of zero, as implied by the second proposition. The data plotted in this graph suggest little relationship between the two. Some countries with extremely high money growth rates have low or even negative growth rates of real income. Bolivia, for example, has a 220 percent average annual growth rate of money even though real income over the period declines at an average annual rate of about 2 percent. Also, Israel's money growth is about 152 per. cent, but real income growth is only 2 percent per year.

In contrast, other countries have relatively low money growth and fast real income growth. Singapore, for instance, has an average real income growth of 8.6 percent over the five years and a 9 percent average money growth rate. This is below the average money growth of 23 percent for all the countries, but well above the average real growth of 2.2 percent per year.

This second proposition also can be examined by regressing real income growth on money growth; the result is presented in the middle row of table 1 . The estimated coefficient on money growth is negative, suggesting that a faster expansion in the money supply lowers real income growth in the long run. Although an increase in money growth is associated with an increase in nominal income growth, the evidence suggests an increase in money growth is associated with a decrease in real income growth. ${ }^{15}$

The final proposition concerns the relationship between money growth and inflation. Is a 1 percentage point increase in the growth rate of money reflected in a 1 percentage-point increase in the rate of inflation? Figure 3 shows money growth and inflation rates across the countries. The visual evidence supports a one-for-one corre-

\footnotetext{
In a regression without Bolivia, the estimated coefficient of money growth is still negative, -0.014 , but is no longer statistically different from zero.
} 
Chart 2

Growth in Real GNP and Growth in Money:

1979 to 1984

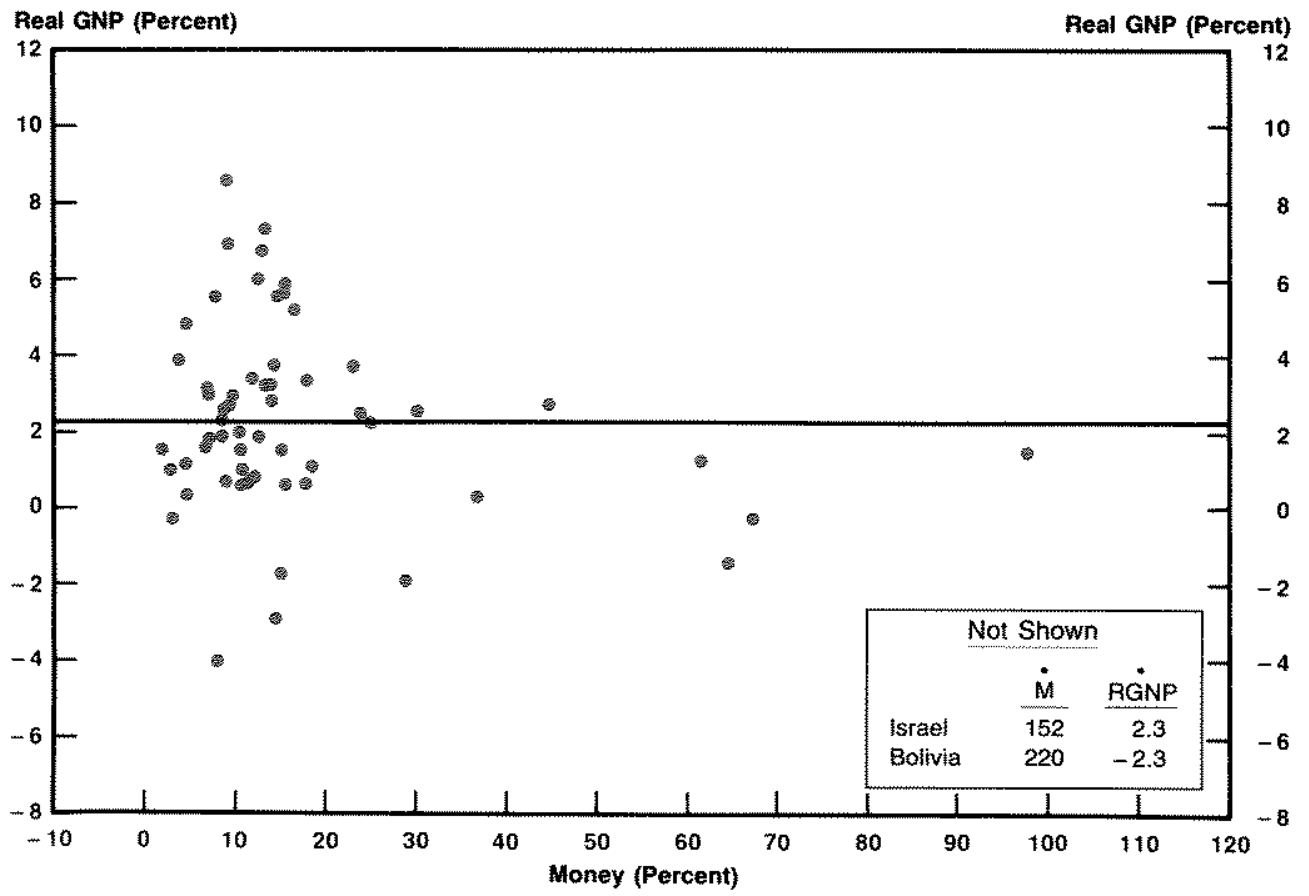

W w

Chart 3

Inflation Rate and Growth in

Money: 1979 to 1984

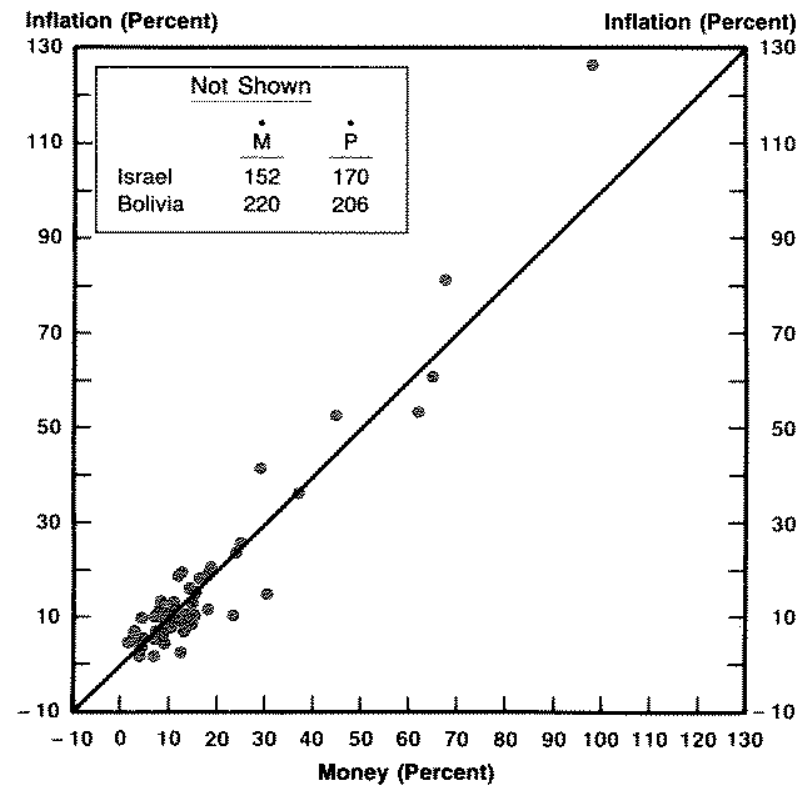


spondence: the points clearly are clustered around the reference line, indicating that countries with higher money growth on average similarly have higher rates of inflation.

The data shown in figure 3 also support this proposition when used in a regression of inflation on money growth. Reported in the last line in table 1 , the regression results are consistent with a one-for-one link between money growth rates and inflation. The estimated coefficient of 1.031 indicates that an increase in the growth rate of money by 1 percentage point is associated with a similar increase in the inflation rate.

To recap the evidence, the data are generally consistent with the propositions set forth above. The data from 62 countries for 1979 to 1984 show that, holding other things constant: (1) there is a one-for-one connection between money growth and nominal income growth; $(2)$ there is little sys. tematic relationship between money growth and real income growth; and (3) there is a one-for-one connection between money growth and inflation, These results are not specific to this particular sample of countries or time period: evidence based on a smaller set of countries (40) for the period 1981-86 supports these same conclusions. . $^{\text {th }}$

\section{The Shor-Term Evidence}

Given the evidence above, why then has the relevance of money come under such strong criticism in recent years? Perhaps one reason is that attempts to apply these long-run propositions to shorter time spans have led to disappointing results and erroneous rejection of the propositions. As Milton Friedman (1986) recently reiterated, the "time delay between changes in the quantity of money and in other magnitudes are 'long and variable' and depend a great deal on surrounding circumstances."

Two single years from the period suffice to illustrate the errors in attempting to use longer-run relationships to explain shorter-run outcomes. One year chosen is 1984, the most recent year for which data for all 62 countries are available. The other is 1979, the beginning of the period. How well do these long-run propositions fare in each year?

Figure 4 shows the data for nominal income and money growth for 1984; the association here appears somewhat looser than shown in figure 1. For instance, in 1984, Peru's money growth rate of 116 percent is associated with 128 percent growth in nominal income, while Iceland's money growth rate of 107 percent is associated with only a 33 percent rate of increase in nominal income. While these two countries offer convenient examples, the variety of income growth rates associated with a given money growth rate is sufficiently large to make the point. For example, 35 percent money growth is associated with nominal income growth rates ranging from 5 percent to 70 percent. $^{37}$

The perception that the link between money and income is looser in 1984 than for the five-year period running from 1979 to 1984 is corroborated by a simple regression. The first row of table 2 presents regression results using data for 1984. The regression of income growth on money growth, unlike its companion equation in table 1, indicates that a 1 percentage-point increase in money growth is not associated with a like increase in income growth. Rather, nominal income growth increases by about three-fourths of a percentage point. This illustrates the point that the one-forme proposition concerning income and money growth does not necessarily hold over shorter periods.s

Figure 5 shows the relationship between nominal income and money growth rates for 1979 . The looseness of the shorter-run association between growth rates of money and nominal income again is evident. On the one hand, Israel and Zaire have nominal income growth rates of 92 percent and 103 percent and money growth rates of 0 and minus 2 percent, respectively. On the other hand, Haiti and Tanzania both have nominal income growth of about 11 percent and money growth
${ }^{16}$ The evidence based on the 40 countries with five-year average data through 1986 is similar. A regression of nominal GNP growth on money growth has a coefficient of 0.970 with a standard error of 0.020 ; a regression of real GNP growth on money growth has a coefficient of -0.012 with a standard error of .015; and a regression of the inflation rate on money growth has a coefficient of 0.965 with a standard error of 0.025 .

${ }^{17}$ For example, Denmark has 35 percent money growth and 9 percent nominal income growth; Ecuador, 36 percent money growth and a 45 percent income growth rate; Bangladesh, 34 percent and 21 percent; Zaire, 38 percent and 68 percent; and Tanzania, 35 percent and 15 percent.

${ }^{18}$ The large outliers in figure 4 are Bolivia, Brazil and Israel. Are these counities responsible for the regression result in table 2 ? Deleting them and re-estimating the income-money equation produces an estimated coefficient of money growth of 0.689 , again different trom unity. 


\section{Chart 4 \\ Growth in Nominal GNP and Growth in Money: 1984}

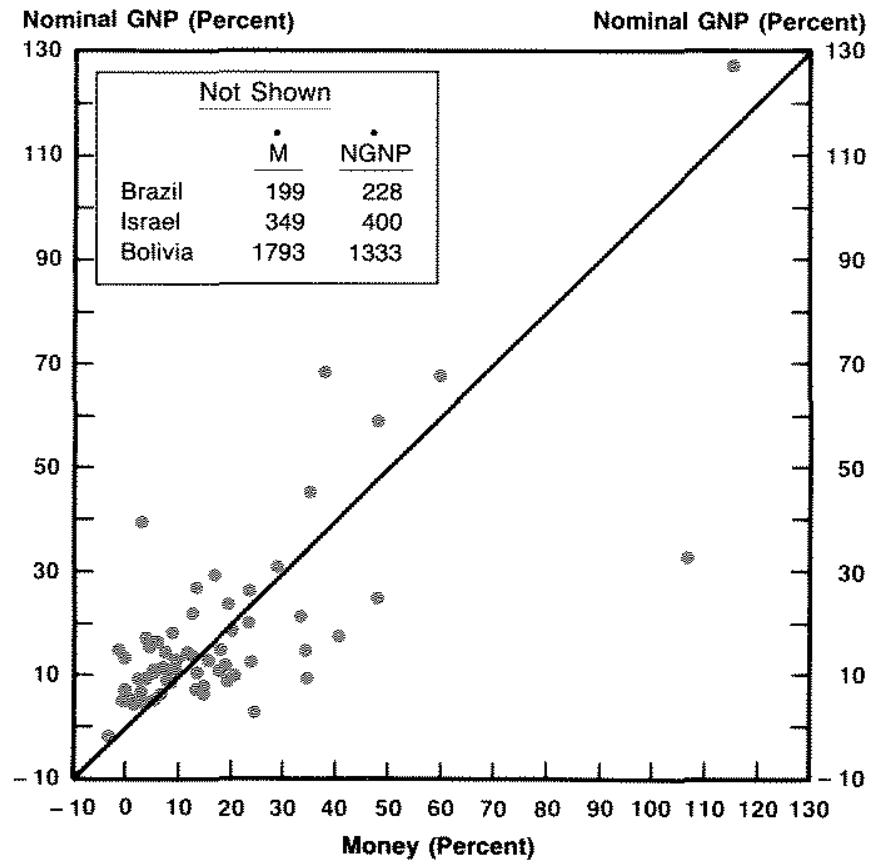

\section{Table 2}

Income and Inflation Regressions: 1979 and 1984

\begin{tabular}{|c|c|c|c|}
\hline \multirow[b]{2}{*}{$\begin{array}{l}\text { Dependent } \\
\text { variable }\end{array}$} & \multicolumn{2}{|c|}{ Cooficiem estinates } & \multirow[b]{2}{*}{ f } \\
\hline & Constant & Growith rate & \\
\hline & 1984 & & \\
\hline Growth rale of & 7.191 & 0756 & 098 \\
\hline nominal ineome & $(3093)$ & $(0,010)$ & \\
\hline Growth rate of & 3.198 & 0.002 & 0.03 \\
\hline $\begin{array}{l}\text { reatingome } \\
\text { hiflation rate }\end{array}$ & $(0.407)$ & $(0.002)$ & 0.98 \\
\hline & $(1,06)$ & 10.013. & \\
\hline & 1979 & & \\
\hline Growturate of & 13.181 & 0.532 & 0.21 \\
\hline 8 nonina iroone & $(3542)$ & $(0.164)$ & \\
\hline Grouthrate of & 3.889 & 0,037 & 0.00 \\
\hline Intlator rate & 9260 & 0,457 & 0.17 \\
\hline & $(8,483)$ & $(0.131)$ & \\
\hline star & & & \\
\hline
\end{tabular}

rates near 54 percent. Clearly, the link between money and income growth rates is much more variable on a one-year basis than over a span of five years.

The regression in table 2 for 1979 confirms that the short-run relationship between money and income is less reliable than the longmun relationship. The coefficient on money growth is only 0.53 , far below unity. Moreover, the $\mathrm{R}^{2}$ which is 98 percent in 1984, is only 21 percent for 1979 . This dramatic switch in results indicates that using money growth to predict nominal income for a period as brief as one year is likely to be associated with large errors. Such short-term inaccuracy, however, does not obviate the underlying, long-run proposition supported by the evidence presented earlier.

Real income and money growth for 1984 are presented in figure 6 . The figtre suggests no discernable pattern. This is consistent with the proposition that real income growth is independent of money growth, even over a period as brief as a year. The associated regression in table 2 corroborates this: the estimated coefficient of money growth is not different from zero. Moreover, 
Chart 5

\section{Growth in Nominal GNP and Growth in Money: 1979}



Chart 6

Growth in Real GNP and Growth in Money: 1984

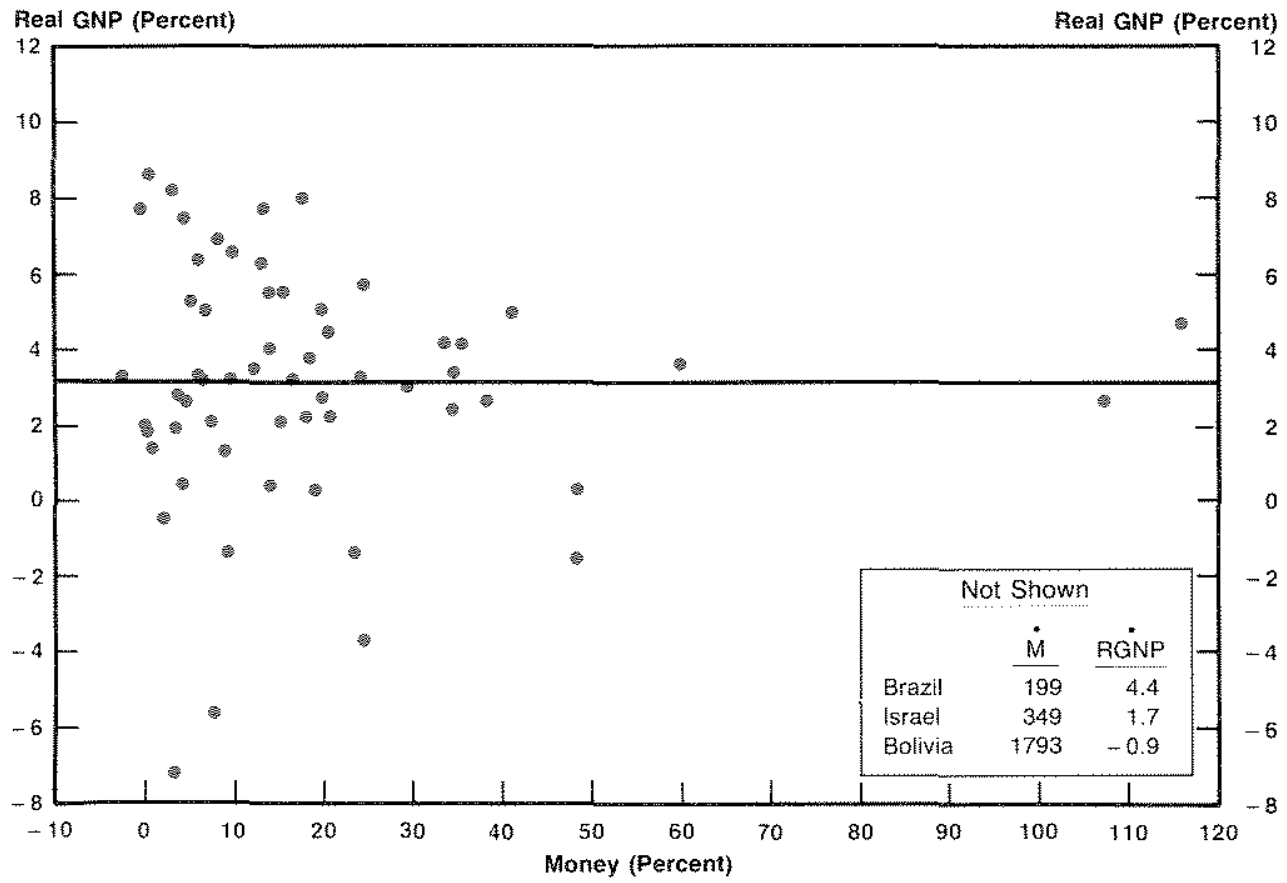




\section{Chart 7}

\section{Growth in Real GNP and Growth in Money: 1979}

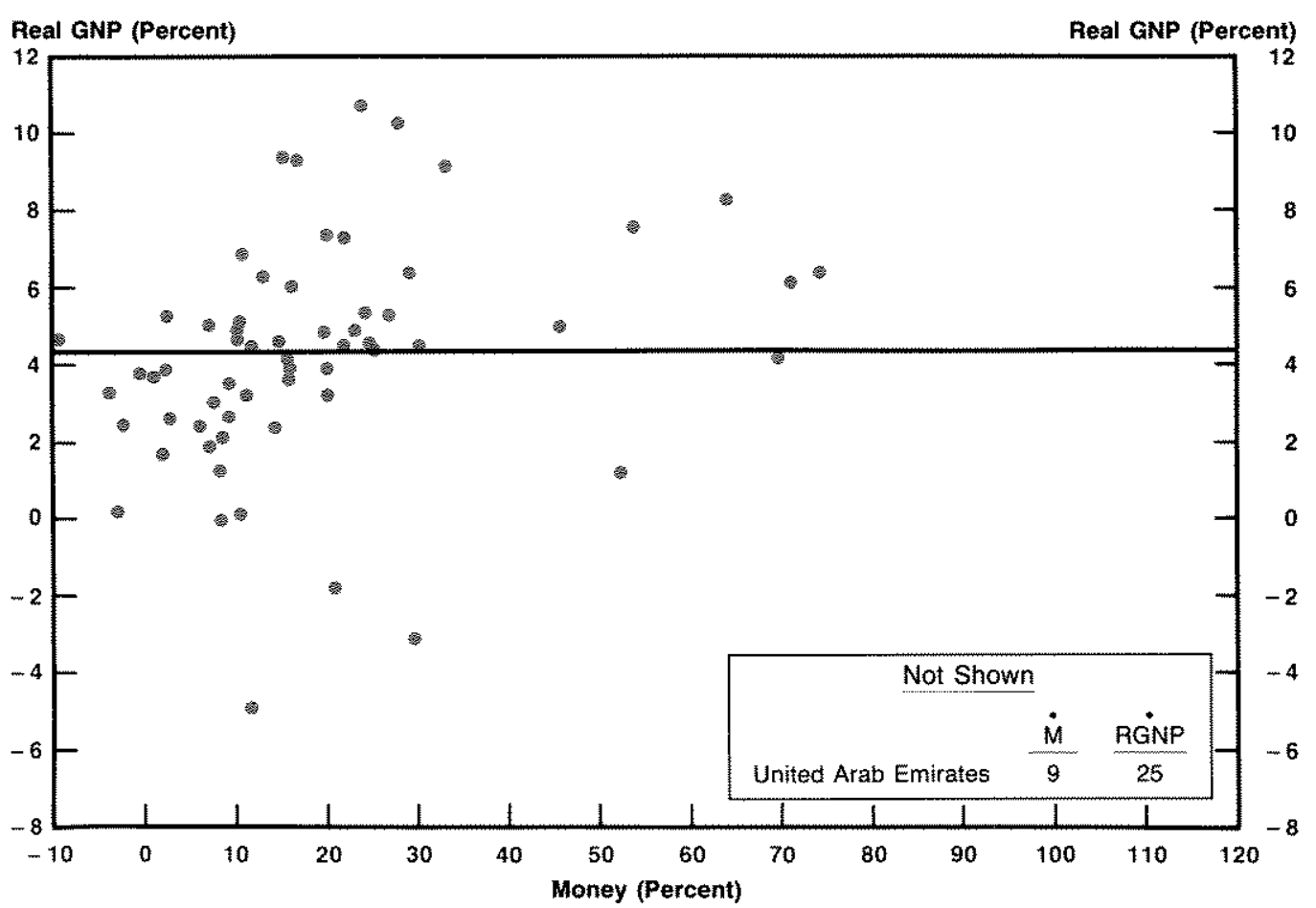

money growth explains a mere 3 percent of the total variation in real income growth. ${ }^{19}$

A similar story unfolds using the data from 1979, which are plotted in figure 7. Austria and Peru provide a taste of this diversity. Austria has real income growth of 5 percent with a money growth rate of minus 9 percent. In stark contrast, Peru has real income growth of about 4 percent with a money growth rate of 70 percent. The regression in table 2 again points to no reliable relationship between money growth and real income growth: the estimated coefficient is roughly zero. The data for 1979 , like the data for 1984 , are consistent with the proposition that the variation of real income growth is largely independent of money growth.

As would be expected based on the results for nominal and real income for these two years, the relationship between money growth and inflation is quite loose in any single year. Figure 8 shows inflation and money growth for 1984. The graph does not suggest the one-for-one relationship found with the data for the five-year period. The relevant regression in table 2 is consistent with this observation. The regression reveals that, in 1984, a 1 percentage-point increase in the growth rate of money is associated with about a threequarters of a percentage-point increase in inflation. Although significant and positive, the association obviously is not one-for-one.

The money growth and inflation data for 1979 , presented in figure 9, show that 1984 is not abnormal. If anything, figure 9 reveals even greater variety in the combinations of inflation and money growth than the data for 1984 reveal. This observation is corroborated by the results of the regression in table 2. In contrast to 1984, the data for 1979 show a weak link between money growth and inflation. Not only is the $\mathrm{R}^{2}$ of the equation low only 17 percent of the variation in inflation is explained by money growth - but the estimated coefficient on money growth again is well below unity. 
Chart 8

Inflation Rate and Growth in Money: 1984

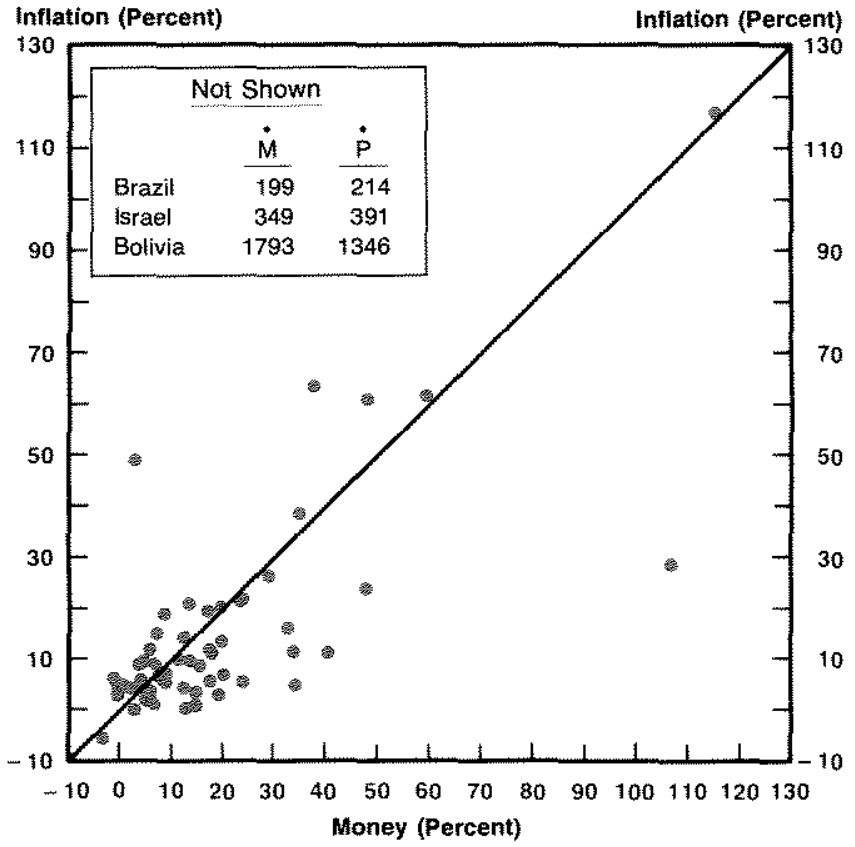

\section{Chart 9}

\section{Inflation Rate and Growth}

\section{in Money: 1979}

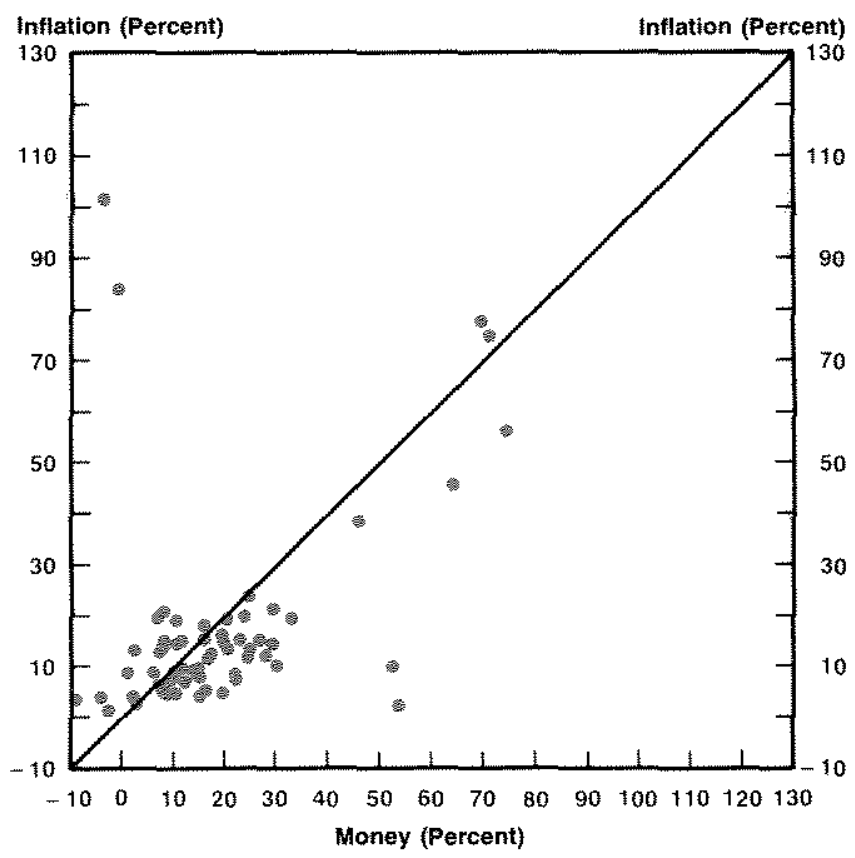


The evidence in this section indicates that money's relevance cannot be judged accurately over shorter-run periods of one month, one quarter or even one year. Over such short-run periods, an increase in money growth may result in a substantial rise in the growth of nominal incomethe evidence from 1984 - or show little effect on nominal income - the 1979 result. Similar results hold when assessing the short-run association between money growth and inflation.

\section{CONGLUSION}

Is money irrelevant? The short-run linkages between the growth rates of money, ineome (both nominal and real) and prices are, as we have shown, quite loose. In any particular year, higher money growth is not associated with an equal increase in nominal income or inflation. Even so, propositions about the importance of money in determining inflation in the longer run have not faded. Viewed in the proper time perspective, a higher growth rate of the money supply is associated with a higher inflation rate. Attempts to use the longer-run relationships between money growth and either nominal income growth or inflation for explaining short-run outcomes are likely to prove disappointing. Money's relevance will be substantially misjudged if attention is focused on the short run.

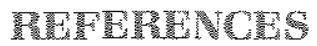

Brunner, Karl. "The Role of Money and Monetary Policy," this Review (July 1968), pp. 9-24.

Fisher, Irving. The Purchasing Power of Money (Macmillan, 1911).

Francis, Darry R. "Has Monetarism Failed? - The Record Examined," this Review (March 1972), pp. 32-38.

Friedman, Mitton. "M1's Hot Streak Gave Keynesians a Bad Idea," Wall Street Journal, September 18, 1986.

Gavin, Willam T., and William G. Dewald. "Velocity Uncertainty: An Historical Perspective," United States Department of State, Bureau of Economic and Business Affairs Working Paper 87/4 (November 1987).

Hume, David. "Of Money," in Writings on Economics, edited by Eugene Rotwein (University of Wisconsin Press, 1970). Reprint of selected essays from Political Discourses, 1752.

Kiborn, Peter T. "Monetarism Falls From Grace," New York Times, July 3, 1986.

Laidler, David E. W. The Demand for Money: Theories and Evidence, 2nd ed. (Dun-Donnelley, 1977).

Lothian, James R. "Equilibrium Relationships Between Money and Other Economic Variables," American Economic Review (September 1985), pp. 828-35.

Lucas, Robert E., Jr. "Adaptive Behavior and Economic Theory," Joumal of Business (October 1986). Part 2, pp. \$40126.

"Two Illustrations of the Quantity Theory of Money," American Economic Review (December 1980), pp. 1005-14.

Pigou, Arthur C. "The Value of Money," Quarterly Joumal of Economics (November 1917), pp. 38-65.

Schwartz, Anna J. "Secular Price Change in Historical Perspective." Joumal of Money, Credit and Banking (February 1973), Part 2, pp. 243-69. 


\section{Data Appendix}

\section{Data for 1979-84}

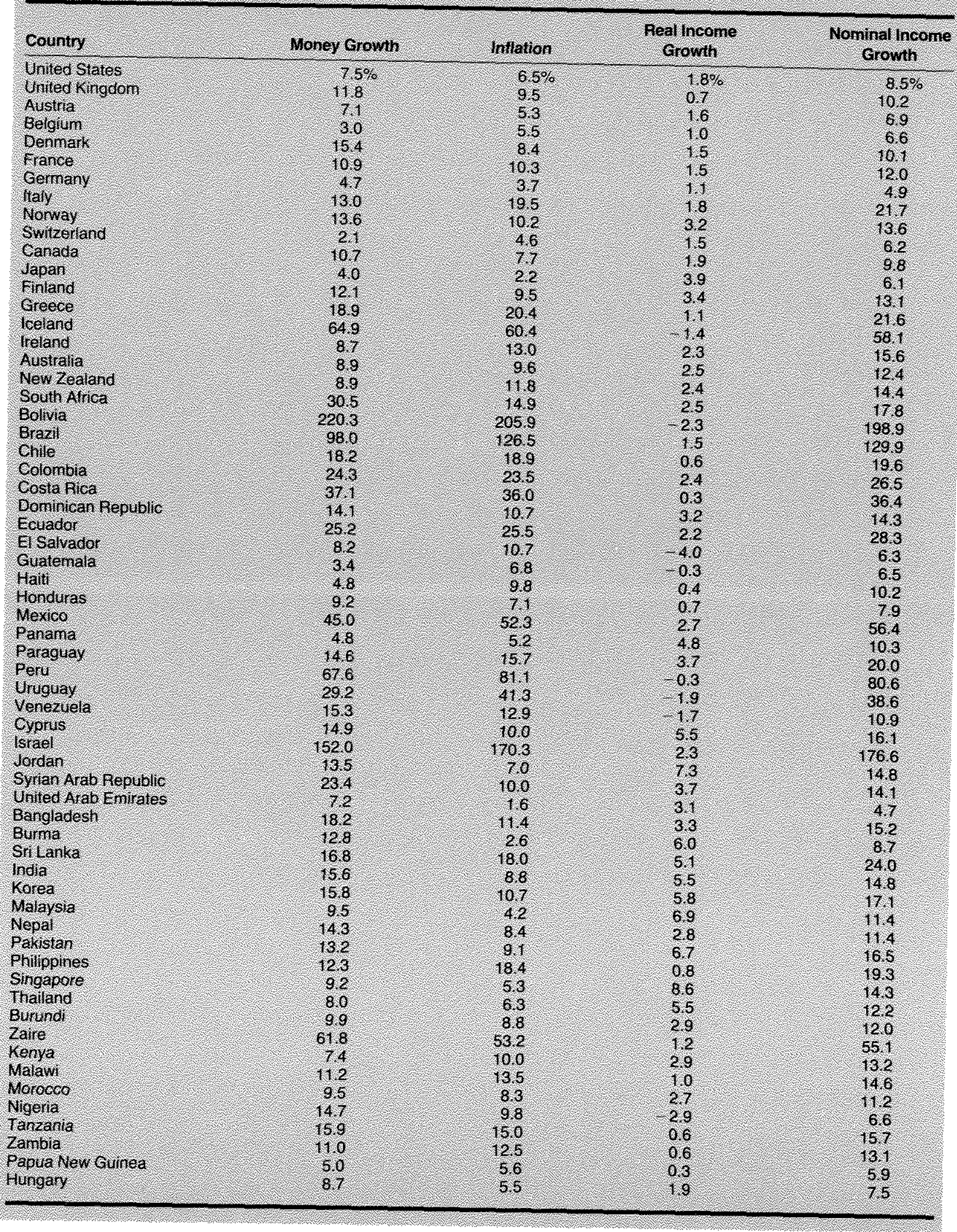


Data for 1979

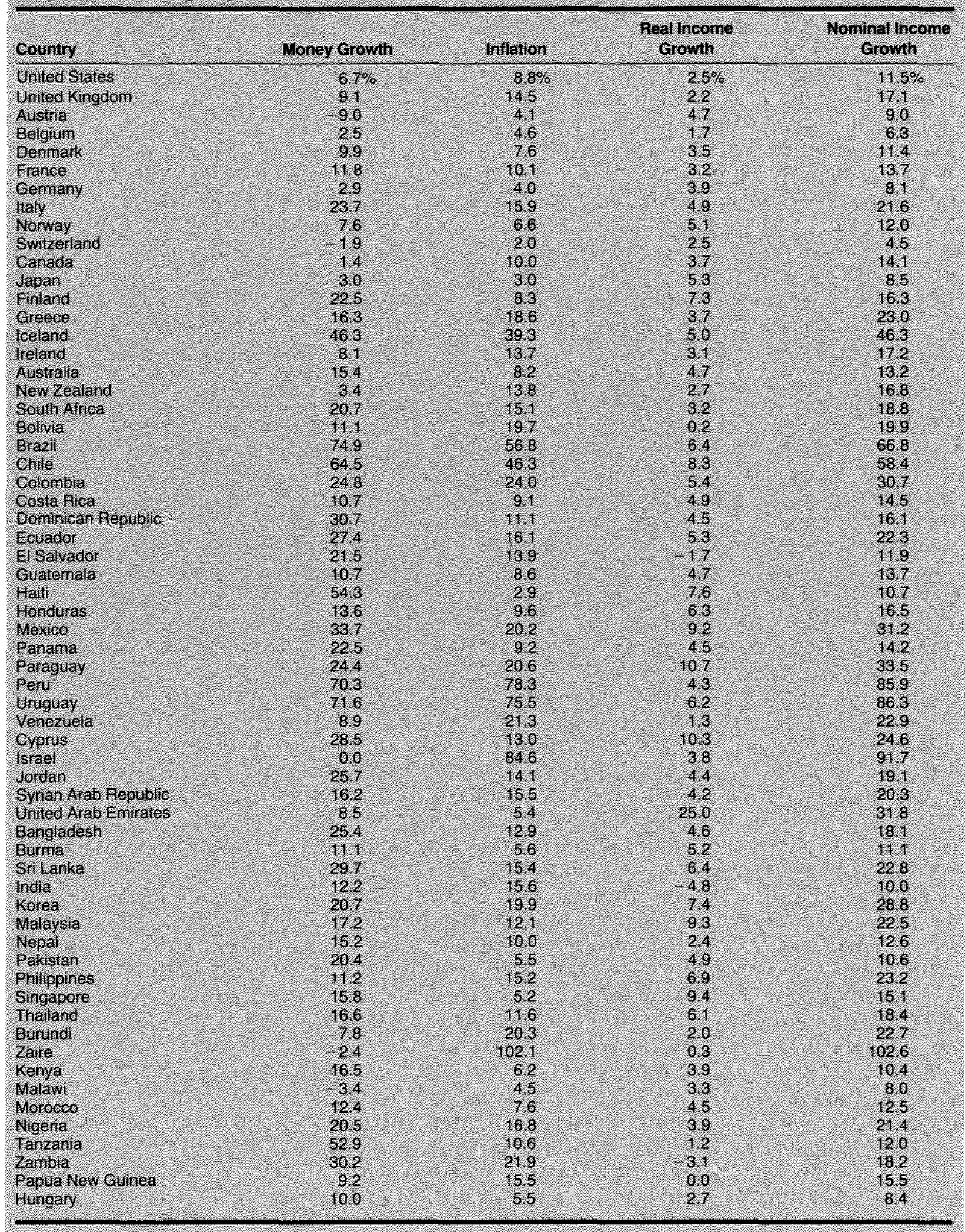




\section{Data for 1984}



